\title{
Curriculum principles, didactic practice and social issues: Thinking through teachers' knowledge practices in collaborative work
}

\author{
Gabriel Bladh*, Martin Stolare and Martin Kristiansson - Karlstad University, \\ Sweden
}

\begin{abstract}
Previous subject-specific education research has shown that education in social studies subjects is dominated by strong subject traditions, while current social issues are seldom addressed and the connection to academic disciplines is weak. Putting this result into context, we discuss how the debate initiated by Michael Young about 'powerful knowledge' as a curriculum principle for the selection of school knowledge gives important theoretical insights. However, we argue that these insights can be developed further by linking them to continental Didaktik theory, in particular to Wolfgang Klafki's models of 'categorical Bildung' and 'critical-constructive didactics' and Ingrid Carlgren's perspective on teaching as different knowledge practices. These ideas make clear the link between the selection of knowledge at curriculum level and the selection and transformation of knowledge at classroom level. Based on this theoretical argument, we discuss how researchers and teachers can collaborate around the selection and transformation of knowledge in a school setting, thereby contributing to a knowledge reservoir for the teaching profession. We conclude with a discussion of an ongoing case study taking place in an upper primary school in Sweden, which exemplifies our theoretical argumentation, showing how a 'time-geographical' perspective can inform teaching about migration as a phenomenon and current social issue.
\end{abstract}

Keywords: social studies subjects; selection and transformation; powerful knowledge; educational potential; knowledge practice; research and development circles

\section{Introduction}

The discussion that has been taking place in the sociology of knowledge about 'powerful knowledge' as a curriculum principle (Young, 2008, 2014) has been an important contribution to the ongoing debate about knowledge, curriculum and the future school (for example, Young et al., 2014; Young and Muller, 2016; Deng, 2018; Nordgren, 2017; Maude, 2018). Young emphasizes the importance of considering pupils' access to 'the best possible' specialized, disciplinary knowledge in education a matter of social justice. This discussion has also inspired our perspective as Nordic researchers in subject-specific didactics, especially with regard to fundamental questions of the selection and transformation of content in teaching and learning.

This article aims to contribute to the debate by problematizing and contextualizing three central themes: (1) Which principles should we draw on when selecting content?; (2) How can we understand educational didactic practices that 
focus on the transformation of content?; and (3) How can researchers' and teachers' differing knowledge bases jointly contribute to the development of knowledge practices in teaching and learning?

We argue that Young's perspective can be clarified and deepened by linking it to continental Didaktik - in particular Wolfgang Klafki's discussions and his models of 'categorical Bildung' and 'critical-constructive didactics'. Inspired by the Swedish educationalist Ingrid Carlgren's perspective on teaching as different knowledge practices, we outline a model for teachers' didactic practices in the classroom. Our third theme deals with methodological perspectives on research, with teachers, on curriculum development and teachers' professional development. Here we highlight a collaborative method in which research and development circles function as a dialogic arena, where teachers and researchers may meet on equal terms to share their different expertise in a learning and development process. Building on our theoretical discussion, the thematic focus is on the content of teaching and learning to better understand and develop teachers' different subject-specific practices. Particularly relevant is what can be termed 'didactical practices' and how they can be developed to support the learning practices of students.

Our empiric context is a recently initiated research project in subject-specific education. Its aim is to develop strategies to make well-founded didactical selections of subject content and transformations in the teaching of social issues in Swedish upper primary school (grades 4-6). Here, we focus on teaching and learning about the social issue of migration in the social studies subjects of civics, geography, history and religion.

We begin the article by describing the background, goals and context of social science education in grades 4-6 in Sweden and identifying some challenges. These challenges are followed up in our theoretical discussion about curriculum principles and teachers' knowledge practices, and in the methodological discussion about research and development circles. This comprises the main part of the article. We then briefly illustrate how we will construct our migration case, and introduce a design prototype based on a time-geographical perspective.

\section{Social studies in upper primary education in Sweden}

Our focus on an upper primary school is unusual for subject didactic researchers. It is more common to focus on the later years in schools when the teachers are more subject-oriented compared to the more pupil-oriented early years teachers. Against the background of school reforms (Utbildningsdepartementet 2009, 2010) in Sweden in the last decade, though, our focus makes sense. What pupils are supposed to know and be able to do is now more strongly framed by school subjects. This framing is visible in the national curriculum which puts forward subject-specific competencies and domain-specific content within subjects as the foundation for teaching and learning in schools. Many teachers in upper primary schools have also been subject to a process of specialization, either focusing on mathematics and the science subjects or Swedish and the social studies subjects. One principal purpose for focusing on school subjects and subject matter has been to counter a negative trend in Sweden concerning pupil achievement (Samuelsson, 2014).

Regarding the social studies subjects, our findings (Bladh, 2014; Kristiansson, 2014, 2017; Stolare, 2014) are similar to those of researchers elsewhere in Sweden (Svingby, 1986; Molin and Grubbström, 2013; Skolverket, 2005) and abroad (see, for example, Brophy et al., 2009; Levstik, 2008; VanFossen, 2005), and does not fulfil the 
hopes behind the reforms. Social studies subjects are neglected at upper primary school and live in the shadow of Swedish, mathematics and the science subjects. This has led to overcrowded, shallow and fragmented content often described as a 'mile wide-inch deep' curriculum. The connection to societal issues outside of school, as well as to specialized state-of-the-art knowledge about society and its issues, is weak. Nor is teaching connected to the everyday lives of the pupils. Our current research circles around this dilemma. The aim is to produce knowledge of what it means to teach content in a more in-depth way by challenging pupils' common sense knowledge through the provision of state-of-the-art knowledge, thus preparing them to handle complex societal issues today and in the future. Within this challenge lies sub-challenges. One challenge concerns what it means to make knowledge about societal issues accessible both thematically and in a subject-specific way, since complex issues often touch upon several disciplines and sometimes go beyond them (Klein, 2006). Another challenge concerns how to relate knowledge as truth-claims to normative claims since coping with complex societal issues such as globalization, climate change and migration often incorporates both types of claims (Habermas, 1999). These challenges point towards the need for change, and we think that the work of teachers has the most critical potential for implementing change (Hattie, 2011).

We have found that teachers view social studies as very important in terms of pupils learning to cope with a complex world and its issues, and they want to change the situation (Kristiansson, 2014, 2017; Stolare, 2014). The problem, from their point of view, is finding the time and the resources to strengthen their ability to make that change happen. For example, Bladh (2014) shows that in-service teachers lack further training in the subjects, making it difficult for new ideas to take root in their teaching.

Our approach is to work together with teachers to create new knowledge about these issues. This approach involves theoretical and methodological considerations that place our project within a broader context that explores the more fundamental questions of what school is for and what it means to select and transform content that is suitable for teaching and learning in school. Reflecting upon this theoretically, we seek inspiration in the current discussion on powerful knowledge, on the one hand, and in the German Didaktik tradition represented by Klafki's work together with Carlgren's ideas about a knowledge practice, on the other. In the next section, we discuss these theoretical considerations in more detail.

\section{Curriculum theory meets Didaktik}

Researchers labelled 'social realists' have been the major actors (Maton and Moore, 2010) in providing a 'knowledge turn' in curriculum theory and educational research over the last decade. Here, 'knowledge about knowledge' in education (Young and Muller, 2016) and, especially, the importance of specialized and differentiated forms of knowledge are central themes. This topic raises questions about principles for a knowledge-led curriculum, but also about how to ensure that children have access to knowledge through specific teaching and learning practices. These basic questions about the selection and transformation of knowledge content in teaching and learning are our focus here. While we are strongly inspired by Anglo-Saxon curriculum theory, our basic theoretical perspectives and concepts are linked to the Continental and Nordic subject didactic research tradition.

The relation between curriculum and didactics has been highlighted in research (Gundem and Hopmann, 1998; Westbury, 2000; Hudson, 2003, 2016; Deng, 2018). Although our purpose here is not to describe in detail the different traditions, we do 
want to highlight some significant differences. While the teacher has the central role in the didactic tradition, the curriculum tradition mainly develops a system-perspective on education. Also, when the curriculum tradition discusses content as objectified content, the didactic tradition also emphasizes the purpose and meaning of subjective content (Hudson, 2003). The dominant tradition of curriculum theory has been primarily concerned with curriculum development at the institutional and programmatic level, while didactics is centred upon curriculum making at the classroom level. However, although these differences can be made ideal-typical (Westbury, 2000), we regard, in line with Lilliedahl (2015), the relationship between curriculum theory and didactics as complex and interwoven, one in which the traditions can be linked through a shared focus on knowledge content. Based on Bernstein, Lilliedahl argues that the selection of educational content and its organization is a matter of recontextualizing principles, and that curriculum and didactics may be understood as interrelated stages of such recontextualization. In the following sections, we will first discuss curriculum principles for choosing content, primarily through making a comparison between Young and Muller and the German educationalist Wolfgang Klafki. This is followed by a discussion of didactic principles of selection and transformation, where we build on the work of Klafki and the Swedish educationalist Ingrid Carlgren.

\section{Powerful knowledge as a curriculum principle}

In our focus on selection and transformation, Michael Young's thesis of 'powerful knowledge' is a curriculum principle of interest. He formulates this principle while dealing with the fact that knowledge in school can also be seen as the 'knowledge of the powerful'. Young points out that the primary purpose of schools and curricula should be to provide all pupils with the best possible knowledge, and that this is an issue of social justice. Young (2014) characterizes powerful knowledge in the following ways:

- It is distinct from 'common sense' knowledge which is acquired through everyday experience, is limited and context-bound.

- It is systematic and therefore its concepts are systematically related to each other as part of a discipline with specific rules and conventions. It can be the basis for generalizations and thinking beyond particular cases or contexts.

- It is specialized and developed - and developing - by specialists within defined fields of expertise and inquiry.

- It is revisable and open to criticism.

Based on such an understanding of knowledge, Young and Muller (2010) discuss three different education scenarios. Here, an unchanging, traditional and under-socialized content-based curriculum perspective (Future 1) is placed against a weakly classified and over-socialized curriculum perspective, where generic skills and competencies are central (Future 2). A third option is Future 3, a curriculum related to the idea of 'powerful knowledge'. This means a 'new and ever-changing balance between the stability of subject concepts (implicit and overemphasized in Future 1 and underemphasized in Future 2), changes in content (underemphasized in Future 1) as new knowledge is produced and the activities involved in learning (overemphasized in Future 2)' (Young, 2014: 68). From a subject-specific perspective, the focus on systematic, specialized content knowledge within the framework of a Future 3 scenario is a fertile starting point. Central to the idea of powerful knowledge are specific concepts, 'big' ideas and perspectives that exist within a specialized, systematic field of knowledge. Such specialized knowledge may be structured in different ways, and will therefore have 
various degrees of verticality and grammaticality (Bernstein, 2000). This provides different conditions for how knowledge is to be sequenced and how different forms of knowledge should be distinguished or combined in different subject areas. However, Young has not proposed how selection and transformation of the content should be made in practice; he sees this primarily as a pedagogical question (ibid.).

\section{Categorical Bildung and educational potential}

We believe that the German-Nordic Didaktik tradition can provide a complementary perspective on the selection of content (see Willbergh, 2016). In German didactic theory, Wolfgang Klafki (1927-2016) was a prominent researcher. Building on his general Didaktik and Bildung theories, he presented a model of categorical Bildung, which he developed into a model for critical-constructive didactics in the 1970s (Klafki, 1985/2001). The objective of the theory of categorical Bildung or formation, which he designed, is found in the concept of 'educational potential'. This is a concept indicating that in their 'didactical analysis', teachers should reflect on the knowledge aspects, that is, the meanings and values, that their selected content and chosen teaching methods could have for their pupils, in a broader and deeper sense. In the model of categorical Bildung, he distinguishes between the material and formal theories of formation and their respective educational content. Material formation theories centre on objective knowledge content (Bildungsinhalt), while formal theories instead prioritize subjective content, that is, its educational substance (Bildungsgehalt). According to Klafki, a single focus on the objective or subjective side is problematic (see Meyer and Meyer, 2007; Willbergh, 2016). A focus on material formation may involve formal and elite teaching (compare Future 1 in Young and Muller, 2010), while formal theories of formation must be applied to some form of content in order not to become hypothetical (compare Future 2, ibid.). Categorical Bildung represents the objective and subjective side of Bildung, dialectically combined. Metaphorically, one can understand the process as a double opening: the pupil opens up to the world and the world opens up to the pupil. Expressed in another way: opening up the educational potential of content is done by constructing teaching situations where 'matter is turned into meaning' for the pupils (Hopmann, 2007). Klafki focuses on three constructed principles that are central to developing categorical Bildung: the elemental, the fundamental and the exemplary. The elemental principle highlights basic knowledge or perspective, which can be understood as 'building blocks' that reveal subject matter (material perspective), while the fundamental principle refers to content that relates to the pupil's basic life experience (formal perspective). Klafki (1985/2001) points to the exemplary principle as being central to teaching. Here the idea is that the specific always represents something general. Categorical formation is about developing important forms of tools for understanding concepts and perspectives, while making them meaningful to the pupils.

In its original form, the purpose of Klafki's model of categorical Bildung was not to develop a specific form of curriculum (for example, to reformulate the traditional subject canon). However, he further developed his model of critical-constructive didactics as general formation and suggested epoch-typical key problems for the core content of a curriculum. Examples include: the question of peace, environmental issues or questions of nationality, the latter involving intercultural or social justice issues. These should be related to a relevant selection of subject teaching. The formative value - the formal perspective - must be seen in relation to the purpose of developing abilities regarding self-determination, co-determination and solidarity in relation to 
the key issues. Thus, different types of emancipatory teaching and learning processes are emphasized.

\section{Curriculum principles in comparison}

We can see that both Young's and Klafki's models and curriculum principles have content knowledge as a common starting point. Young's curriculum principle of 'powerful knowledge' has, above all, the character of a basic material formation theory, in which content structure, central concepts, big ideas and perspectives are highlighted. At the same time, there is no explicit, formal perspective on the content knowledge. This can, of course, be understood in the context of the dualistic nature of the interplay between curriculum and pedagogy which characterizes Young's model. As a result, the relationship between curriculum and pedagogy is not developed further. Klafki's didactic model, on the other hand, emphasizes educational potential as a vital selection principle, where the teacher's didactic choices are essential.

The geography education researcher Maude has pointed out that in some cases, Young also presents an alternative way of thinking about the concept of 'powerful knowledge', focusing on 'what the knowledge does for those who have it' (Maude, 2018; also compare Lambert, 2016, on capabilities and 'powerful knowledge'). Such a perspective is closer to Klafki's connection to formal (and categorical) formation. This means, however, that the relationship between curriculum and pedagogy is considered relationally, which is characteristic of didactics and subject didactics. We argue that Klafki's classification of the material and formal theories of Bildung make an important contribution to the discussion of how powerful knowledge can be viewed.

In his constructive-critical didactic theory, Klafki points out that the epochtypical key problem has unique educational potential for children and young people, and should be the focus of the curriculum. He emphasizes that teaching should be connected to the disciplines, although it should not be perceived as mirrors of them. In line with the idea of categorical Bildung, there is no clear-cut selection criterion to be found in the discipline itself. When making didactical choices, the discipline is a resource for the teacher. Klafki's discussion, influenced by critical theory, also problematizes the role of the disciplines, pointing to the links between knowledge and values. The emphasis on key problems also opens up the issue of whether a curriculum should be principally disciplinary or thematic (Meyer and Meyer, 2007). However, it is not obvious to what extent this means a weak classification of the curriculum in Bernstein's sense (Bernstein, 2000). Young and Muller (2010) stress the importance of maintaining the fundamental boundaries of disciplinary knowledge as well as a strong classification. Further, in their texts, there is no elaboration of how the relationship between 'powerful knowledge' and 'knowledge of the powerful' should be considered in educational practice. So, there is a tension between knowledge and values, which needs further consideration.

Both Klafki and Young and Muller point out that a curriculum changes with the development of knowledge and alongside societal changes. The canon of school subjects needs to be reviewed constantly. Both perspectives provide fruitful contributions to a discussion of the principles of selection and, based on our review of Young and Muller and Klafki, we have established a conceptual map (at a principal curriculum level) summarizing the above discussion (see Figure 1). 


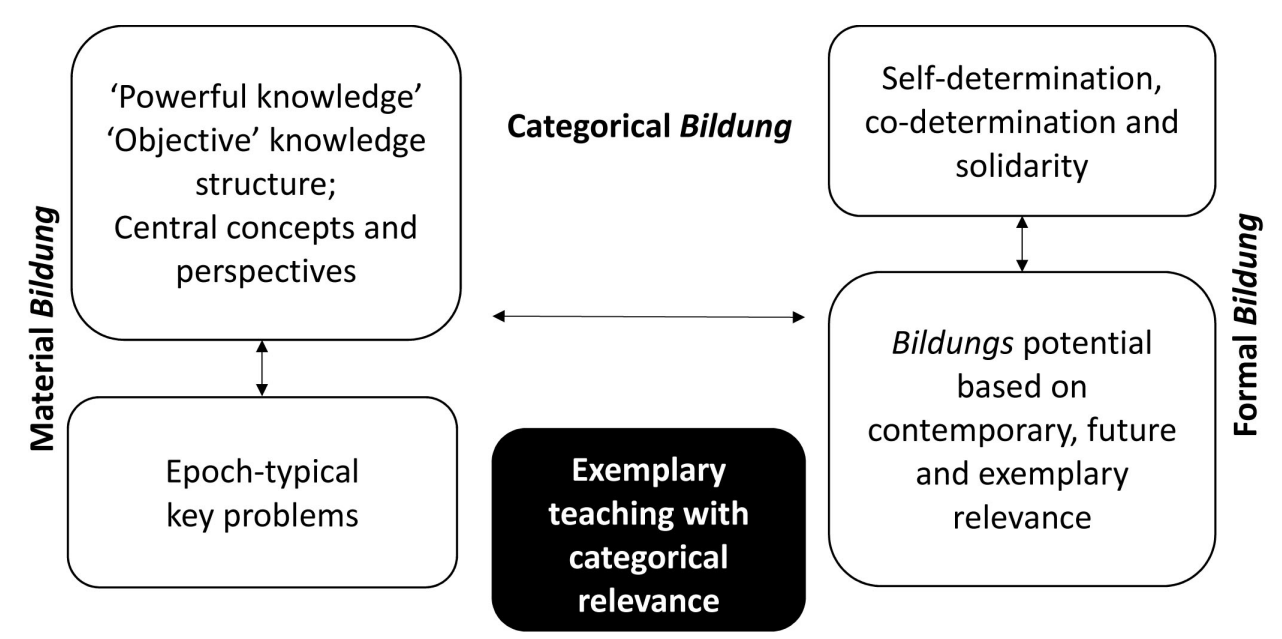

Figure 1: Principal conceptual map for the selection of content for teaching social issues: curriculum level

None of the researchers, however, has exemplified specific, detailed curriculum content. In this regard, we suggest that subject didactic research can provide in-depth contributions.

\section{Teachers' didactical choices: Teaching as didactical practice}

In his discussion of curriculum thinking and curriculum making as the practical fusion of curriculum and pedagogy, Lambert (2014) points to the importance of reflective and professional teachers as central actors in forming a knowledge-led school. Curriculum thinking is characterized by teachers making didactical choices and reflecting on their goals and purposes. This type of curriculum thinking in the form of didactic analysis has been a central part of Klafki's didactic theory.

The model for teachers' 'didactical analysis' is an important clarification of Klafki's categorical Bildung as a strategy for selecting teaching content (Klafki, 2000). The analysis can also be described as a framework for thinking about the transformation of content. Klafki argues that the general always has to be observed within the concrete and specific. At the classroom level, exemplary teaching represents an implementation of the epistemology of categorical Bildung (Willbergh, 2016). The content is essential in Klafki's analysis; the basic model consists of five questions that could be applied in analysing the didactic situation from the perspective of the teacher:

1. What general sense, basic phenomena or fundamental principal does this content exemplify and open up to the learner? (exemplary significance)

2. What significance does the content in question already have in the minds of the children in my class? (contemporary significance)

3. What constitutes the topic's significance for the children's future? (future significance)

4. How is the content structured (which has been placed in a specific pedagogical perspective by questions 1,2 and 3 )? (the structure of the content)

5. What are the special cases, phenomena, situations, experiments, persons, elements of aesthetic experience, and so forth, in terms of which the structure of the content in question can become interesting, stimulating, approachable, conceivable or 
vivid for children of the stage of development of this class? (accessibility) (Klafki, 2000: 152-5)

The structure of the content (question 4 above) is emphasized in Klafki's analysis model. This is also an important point in the discussion regarding the transformation of powerful knowledge, for instance: to what extent is the content hierarchically structured and need to be sequenced (Young and Muller, 2016)? However, for Klafki, the content is placed in the context of its educational potential regarding the present, future and exemplary relevance for the pupil. The relationships between content, teacher and pupil are clear in the five analytical questions above, which underline the relational perspective in the didactic tradition. The questions also involve what might be described as Klafki's governing principle: the didactical what and why questions precede the methodological question of how. In his constructive-critical didactics, he further develops this and emphasizes that the aim of teaching always takes precedence. An educational theme needs to be seen in the perspective of specific problems that can be related to the pupils. However, his discussion about methodological structuring and how the teaching-learning process should be structured is less developed.

The Swedish pedagogue Ingrid Carlgren has argued that knowledge is developed in, and as part of, practical activities. For example, understanding concepts requires that they are used in contexts in which they play a role. This reflects an understanding of knowledge that is relational and practice-based, and which problematizes the act of reducing knowledge to theoretical statements of knowledge. Based on Carlgren (2015), we view teaching as an activity that consists of performing or orchestrating different knowledge practices. Teaching might be framed as an activity that creates situations for learning. Teaching as a didactic practice indicates that the teacher must design and establish a knowledge practice and make it function as a learning practice for the pupils (see Figure 2). This is a knowledge practice that also involves the aspect of doing, and also means that pupils must perceive the situation as functional and motivational, and accept the rules of the game in line with the didactic contract between pupil and teacher.

Young and Muller (2016) discuss, with reference to Winch (2010), how various forms of specialized knowledge are incorporated in expert knowledge. Both 'knowthat' knowledge and 'know-how' knowledge is needed. In addition to propositional knowledge, expert knowledge is also connected to inferential and practical knowledge, and various kinds of more or less specialized procedural knowledge. We think the relations between different forms of knowledge are a key aspect of teaching as a didactic practice. The teacher needs to create knowledge practices that combine and relate different forms of knowledge to the specific content knowledge and learning object. Here curriculum thinking formed as didactic analysis can make important contributions.

The perspective of didactic practices has many similarities with the framework discussed as curriculum making in British geography education (Lambert, 2014). Curriculum making can be understood as merging the conceptually distinct categories of curriculum and pedagogy. This again underlines our point that stresses the importance of the relational perspective in the didactic tradition, which puts teachers' didactical choices and their didactic practice in focus. 


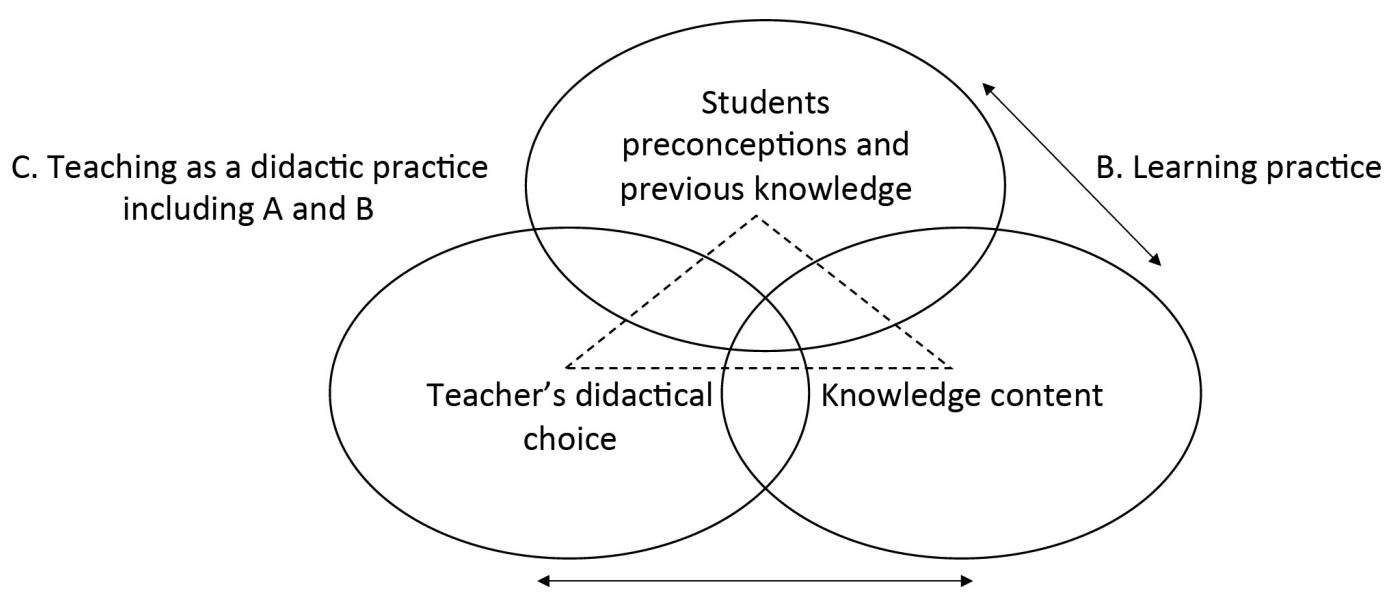

A. Knowledge practice viewed as a knowledge (re)construction practice

Figure 2: Model of the teacher's didactic practices: Selection of content at the classroom level (drawing on Carlgren, 2015)

\section{Research and development circles as arenas for curriculum development}

Selection and transformation as the principal dimensions in a complex didactic practice, where the levels of curriculum and classroom are interwoven, have been the nexus of the argument so far. We believe close collaboration between teachers and researchers is needed if the ambition is to deepen the understanding of the didactic practice. A vital resource in this development work is teachers' in-depth perspective on didactical practices as well as the researchers' disciplinary methodological and analytical knowledge. Our response to these challenges, which requires different knowledge bases, is to initiate what we call subject-specific didactic research and development circles with in-service teachers (Stolare, 2014, 2017; Kristiansson, 2014, 2017).

In the Swedish context, research circles are a strategy that has been adopted to develop different types of public services such as the police, social care, healthcare and, not least, schools. Research circles have been identified as a way to achieve school improvement (Persson, 2009). A research circle is a group of four to eight participants - in our project, in-service teachers - who work together with researchers on a jointly formulated problem for a period of time. The aim of the work of the circle is to gain a better understanding of the chosen problem, which ultimately is expected to strengthen the public services concerned (Holmstrand, 2008). Methodologically, research circles have been associated with action research and are considered to be interactive and participant-oriented, in the sense that symmetrical interaction between the participants in the circles is crucial for achieving the desired outcomes (Holmstrand, 2008; Kemmis et al., 2014).

The roots of research circles are to be found in study circles, which were developed in the context of the nineteenth-century Swedish folk movement. In study circles, the educational perspective is important and the aim is the emancipatory empowerment of the individual (Arvidson, 1991; Stolare, 2010). The research circle can be described as a study circle led by a researcher, where, as indicated, the purpose is to develop knowledge of a jointly formulated problem or challenge (Starrin and Lundberg, 1993). 
By naming them research and development circles, we want to highlight the dual function of the circles. They are an instrument for developing the context in which they are set, improving teaching and strengthening the professional identity of the participants in the circle. However, in research circles with a subject didactic approach, where the goal is to develop lesson plans and teaching modules, a horizontal relationship between the participants in the circle is not an end in itself. The idea is that the circles should function as a platform for generating knowledge that is not entirely contextually bound. The circles are organized in two phases.

\section{The two phases of the research and development circles}

The study circle constitutes the first phase of the research and development circles. In this phase, the problem is jointly defined by the participants and understanding of the problem is deepened through reading and reflecting on appropriate literature. The relevance of specialized knowledge is discussed in relation to didactic practices and its educational potential. In this discussion the different experiences and perspectives of teachers and researchers come into play. In the initial phase the work in the circles addresses the curricular level, but does so without either losing the connection to the classroom level or to perspectives on educational practices. Here teachers and researchers jointly initiate a didactic analysis of potential teaching content (Klafki, 2000). In this way, questions about teachers' didactic selections and the process of transformation are approached and discussed as expressions of didactic practices (Carlgren, 2015). The expected outcomes of these discussions are preliminary ideas about exemplary lesson plans and modules with categorical relevance (Klafki, 2000; Andersson, 2005). The subject didactic focus of the circles have an impact on how they are organized and structured. A vital part of the first phase of the circles is to thoroughly problematize and discuss the potential teaching content and the knowledge it represents (see Lambert, 2014, on curriculum thinking). This is done through sharing state-of-the-art research (specialized knowledge), which the teachers read in the light of their experiences of teaching conditions, but also in relation to the potential for learning and the overarching goals of education. The latter is captured in Klafki's concept of codetermination, self-determination and solidarity (see Figure 1). For teachers, this is a way to conquer in-depth and renewed knowledge about content that they may not have studied for a long time. In the process, teachers internalize concepts that enable them to relate more closely to the possible content of teaching. The tacit knowledge, developed through the practice of teaching, can be articulated using concepts that the teacher may not have encountered before. For the researchers, this first phase makes it possible to get a contextually based understanding of the prerequisites of teaching. The fact that the participants are anchored in different knowledge practices - universities and schools (compare Figure 2) - contributes to the composition of the conceptual ideas that emerge in the circle.

The second phase of the circles is more concrete and practical as the emphasis moves to the systematic development of lesson plans and teaching modules. The circles' role as knowledge-generators is an aspect of the first phase that is further strengthened in phase two. Here, the circles and their participants work together to solve the problem/challenge they formulated, clarified and deepened during the first phase. An essential aspect of the didactic analysis in this phase is to determine the extent to which lesson plans and teaching modules actually could be of categorical relevance. During the second phase, the classroom practices are allowed to dominate the perspective of the circles. Central, then, is an in-service view, expressed as teachers' understanding of didactic practice. At the same time, is it the researchers' mission to 
constructively question the tendency to path dependency that can be identified in those practices. The effort to develop lesson plans and tasks brings the relationship between different forms of knowledge to the surface. With the emphasis on specific tasks, the aspect of enacting the subject matter 'know-how' is brought to the foreground (Winch, 2013). In that situation, teaching is perceived as an expression of different didactic practices (see Figure 2). In all, phase two deals with how knowledge is transformed or (re)contextualized by the teacher and how the teacher, together with the pupils, establishes a knowledge practice, while making room for the learning practice of the pupils.

The work on the concrete development of teaching materials can be characterized as a design-based approach (Nieveen and Folmer, 2013; van den Akker et al., 2006). The prototypes of lesson plans and teaching modules are tested in different contexts and various questions are foregrounded to detect aspects that need further clarification and attention. This is framed as an iterative process. One main purpose of the research and development circles is to contribute to professional development beyond the local setting of the circles. It is a way to provide a reservoir (Bernstein, 2000) of knowledge for teachers outside the circle to draw on to develop their repertoire when teaching about migration and other social issues.

\section{Prototypes and design principles: The example of migration and time-geography}

So far the discussion in this article has been held at the principle level. There is a need to concretize the argument by relating it to an ongoing project focusing on teaching about social issues, specifically migration, in Years 4 to 6 in upper primary school. The aim of this project is to investigate and problematize how teaching about migration in primary schools can be connected to specialized knowledge. At the same time, our ambition is to discuss the interplay between dimensions of knowledge and value in a social issue such as migration. The latter becomes a matter of safeguarding the societal relevance of social studies subjects. Migration is a phenomenon that has generated massive amounts of social science research. We want to investigate the possible specific educational relevance of that research. Our understanding is that the link between specialized knowledge and educational potential are of utmost importance. We also recognize that disciplinary perspectives benefit from a subjectspecific didactic analysis. The framed problem can be made concrete by two empirically linked questions. What important ideas, key concepts and theories in social science research are especially relevant to migration as a theme? Can we identify perspectives and knowledge dimensions that might have educational potential for 10 to 12-year-old pupils in this context?

Our ambition is to define, on the basis of research and development circles, content-impregnated design principles for teaching about migration in upper primary school. Based on our conceptual map for selecting content for teaching on social issues (see Figure 1), we understand migration as a phenomenon that, in many ways, can be linked to what Klafki (2000) defines as epoch-typical key problems.

To understand the question of why one migrates, and the relationship between migration and residence, the dimensions of time and space are essential, as well as how the interplay between individuals, the collective and societal conditions are structured. The time-geography perspective, developed by the Swedish geographer Torsten Hägerstrand (1985, 2009), and linked to social theory by Allan Pred (1990), provide the prerequisites for approaching such an understanding. Time-geography can be seen 
as a world view, a description-model or as a research programme. It is based on a time-spatial world view within which a world of people, things and places form a weave of patterns and contexts - the weave of existence. The time-geography perspective unites a graphical and concept-based description in a constructive way. The graphic design language and the notation system can be seen as a visual Esperanto (Thrift, 2005), which can be linked to elementary building blocks and concepts (for example, path and project) to capture human actions in their primary context (see Pred, 1990; Giddens, 1984).

We think the time-geography perspective can provide an example of a social science theory - specialized 'powerful knowledge' - that can function as a catalyst to the development of didactic practices. We say this on the basis of our previous pilot studies (Bladh et al., 2017). Our hypothesis is that the time-geography perspective has the potential to be developed into fruitful learning and knowledge practices for pupils in upper primary school. In connection to these pilot studies, we see that the multimodal expression - the combination of graphics and linguistic expressions in the form of notations, concepts, stories and images - has a particular educational potential. In our pilot studies, a person's biography is linked to a simple timegeographical model of the individual's relocation project. The model is an example of a possible prototype, where subject didactical design principles can be applied and developed.

Another example answers the question 'Which contexts determine or provide the conditions for an individual's migration?' The concept of 'institutional projects' (Pred, 1990) provides the opportunity to follow how individuals' migration projects are determined by different social institutions (in a broad sense) such as the family, company and workplace or state.

In both these examples there are elements of oscillating between micro- and macro-perspectives, between insight and overview, between actor and structure, and between change and continuity. The examples represent new methods and practices that differ from how education in social studies is traditionally organized, potentially connecting what is taught in social studies to a stronger disciplinary foundation which makes pupils' understanding of actions on social issues such as migration more resourceful and powerful.

Migration is a phenomenon studied in many different social science disciplines (Hanlon and Vicino, 2014). At the classroom level we have framed migration as thematic teaching content, creating conditions for reflecting on the extent to which specialized knowledge and 'powerful knowledge' should be perceived as disciplinary. Have some of the disciplinary perspectives more weight than others when it comes to the issue of migration? How is the content from different disciplines combined? Questions like these make the formation of a didactic practice complex, to say the least. In the pilot studies we have tentatively identified perspectives and concepts that are common to the different social science disciplines and relevant to the social studies subjects in upper primary school.

In Klafki's perspective, we have searched for the elementary and the fundamental principles (see the section on categorical Bildung) to achieve an understanding of migration as a societal phenomenon. We have identified some concepts and approaches in the time-geographical example, such as micro-macro, actor-structure, change-continuity, which could be understood as elementary and a multi-modality that leans towards being a fundamental aspect in learning practice. Those principles also connect to the idea of epistemic ascent (Winch, 2010, 2013), that is, how knowledge can be categorized and how the relationship between different kinds of knowledge can 
be described from the point of view of supporting the progression of learners. These are preliminary results that need to be scrutinized further. In our view this stresses the importance of didactic analysis (or curriculum thinking) and points to the ability of the teacher (and the researchers in the circles) to balance the understanding of the educational potential of the selected disciplinary content with the overall goals of education. Finally, this is also an example of how subject-specific didactic researchers can make a contribution to the process of curriculum development, working with content-specific didactical knowledge in the form of 'didactical structures' (Lijnse and Klaassen, 2004).

\section{Closing remarks}

Referring back to our questions in the introduction, in this article we have discussed principles for the selection and transformation of content through a meeting between curriculum theory and Didaktik. We acknowledge the work of Young and Muller and their discussion on the principles of content selection for a knowledge-led curriculum, but argue that Klafki's ideas of categorical Bildung and educational potential give fruitful perspectives on how 'powerful knowledge' can be viewed. We stress the significance of the relational perspective in the didactic tradition, which put teachers' didactical choices and their didactic practice in focus. We have also emphasized the importance of establishing strong links between the curriculum level and the classroom level, which is possible through a practice-oriented approach in line with Carlgren. Didactic analysis or curriculum thinking can be regarded as a central tool when teachers' connect their knowledge practices with the selection and transformation of content. The point of departure for the research and development circles, which we identify as arenas for collaborative curriculum development, is framed by us as researchers. However, the outcome of the project will mainly rely on the fruitful interplay between the knowledge base of the teachers and the joint evaluation of actual knowledge practices. We would argue that this type of research could be seen as taking small, but relevant, steps towards a Future 3 curriculum.

\section{Notes on the contributors}

Gabriel Bladh is Professor in Social Science Education at Karlstad University. His current research focus is on subject-specific education, especially geography education, as a thematic field. He is also Associate Professor (docent) in Human Geography, and his areas of specialization include outdoor education, landscape research, theoretical perspectives connected to nature-society relations and the history of geographical ideas.

Martin Stolare is Associate Professor in History at Karlstad University. In his research, he focuses on primary school and teaching and learning in history and social studies. With a background as a historian, a particular interest of his is the interplay between history as a discipline and as a school subject. In the last decade he has run several practice-based research projects with in-service teachers.

Martin Kristiansson is Lecturer in Pedagogy at Karlstad University. He has a particular interest in studying teaching and learning in civics as a social studies subject in upper primary school. This interest is mainly practice-oriented, where cooperating with inservice teachers serves a dual purpose of contributing to knowledge for research as well as for teaching. 


\section{References}

Andersson, B. (2005) Design och validering av undervisningssekvenser: En ämnesdidaktisk forskningsstrategi med exempel från naturvetenskap. Göteborg: Institutionen för pedagogik och didaktik.

Arvidson, L. (1991) Folkbildning och självuppfostran: En analys av Oscar Olssons idéer och bildningssyn. Stockholm: Tiden.

Bernstein, B. (2000) Pedagogy, Symbolic Control and Identity: Theory, research, critique. Rev. ed. Lanham, MD: Rowman and Littlefield.

Bladh, G. (2014) 'Geografilärare och geografiundervisning i den svenska grundskolan: Några delresultat av en enkätstudie'. Geografiska Notiser, 72 (4), 158-68.

Bladh,G., Kristiansson, M. and Stolare, M. (2017) 'To develop teaching on social issues: Content selection and transformation in social studies education in upper elementary school, year 4-6'. Paper presented at the NOFA6 Conference, University of Southern Denmark, Odense, 29-31 May.

Brophy, J., Alleman, J. and Knighton, B. (2009) Inside the Social Studies Classroom. New York: Routledge.

Carlgren, I. (2015) Kunskapskulturer och undervisningspraktiker. Göteborg: Daidalos.

Deng, Z. (2018) 'Bringing knowledge back in: Perspectives from liberal education'. Cambridge Journal of Education, 48 (3), 335-51.

Giddens, A. (1984) The Constitution of Society. Cambridge: Polity Press.

Gundem, B.B. and Hopmann, S. (eds) (1998) Didaktik and/or Curriculum: An international dialogue. New York: Peter Lang.

Habermas, J. (1999) Den postnationella konstellationen. Göteborg: Daidalos.

Hägerstrand, T. (1985) 'Time-geography: Man, society and environment'. United Nations Newsletter, 8, 193-216.

Hägerstrand, T. (2009) Tillvaroväven. Stockholm: Forskningsrådet Formas.

Hanlon, B. and Vicino, T.J. (2014) Global Migration: The Basics. New York: Routledge.

Hattie, J. (2011) Visible Learning for Teachers. London: Routledge.

Holmstrand, L. (2008) 'Forskningscirklar: Ett sätt att demokratisera kunskapsbildning?'. In Johannisson, B., Gunnarsson, E. and Stjernberg, T. (eds) Gemensamt Kunskapande: Den interaktiva forskningens praktik (Acta Wexionensia 149). Växjö: Växjö University Press, 189-203.

Hopmann, S. (2007) 'Restrained teaching: The common core of Didaktik'. European Educational Research Journal, 6 (2), 109-24.

Hudson, B. (2003) 'Approaching educational research from the tradition of critical-constructive Didaktik'. Pedagogy, Culture and Society, 11 (2), 173-87.

Hudson, B. (2016) 'Didactics'. In Wyse, D., Hayward, L. and Pandya, J. (eds) The SAGE Handbook of Curriculum, Pedagogy and Assessment. London: SAGE Publications, 107-24.

Kemmis, S., McTaggart, S. and Nixon, R. (2014) The Action Research Planner. Singapore: Springer.

Klafki, W. (1985/2001) Dannelseteori och Didaktik - Nye studier. Klim: Aarhus.

Klafki, W. (2000) 'Didaktik analysis as the core of preparation of instruction'. In Westbury, I., Hopmann, S. and Riquarts, K. (eds) Teaching as a Reflective Practice: The German Didaktik tradition. London: Routledge, 139-60.

Klein, J. (2006) 'A platform for a shared discourse of interdisciplinary education'. Journal of Social Science Education, 5 (2), 10-18.

Kristiansson, M. (2014) 'Samhällskunskapsämnet och dess ämnesmarkörer på svenskt mellanstadium: Ett osynligt eget ämne som bistår andra ämnen'. Nordidactica, 1, 212-33.

Kristiansson, M. (2017) 'Underordnat, undanskymt och otydligt: Om samhällskunskapsämnets relationsproblem inom SO-gruppen på svenskt mellanstadium'. Acta Didactica Norge, 11 (1), Article 4, 1-20. Online. www.journals.uio.no/index.php/adno/article/view/2547/3991 (accessed 24 July 2018).

Lambert, D. (2014) 'Subject teachers in knowledge-led schools'. In Young, M., Lambert, D., Roberts, C. and Roberts, M. Knowledge and the Future School: Curriculum and social justice. London: Bloomsbury Academic, 159-87.

Lambert, D. (2016) 'Geography'. In Wyse, D., Hayward, L. and Pandya, J. (eds) The SAGE Handbook of Curriculum, Pedagogy and Assessment. London: SAGE Publications, 391-407.

Levstik, L.S. (2008) 'What happens in social studies classrooms? Research on K-12 social studies practice'. In Levstik, L.S. and Tyson, C.A. (eds) Handbook of Research in Social Studies Education. New York: Routledge, 50-62. 
Lijnse, P. and Klaassen, K. (2004) 'Didactical structures as an outcome of research on teachinglearning sequences?'. International Journal of Science Education, 26 (5), 537-54.

Lilliedahl, J. (2015) 'The recontextualisation of knowledge: Towards a social realist approach to curriculum and didactics'. NordSTEP: Nordic Journal of Studies in Educational Policy, 1, 40-7.

Maton, K. and Moore, R. (eds) (2010) Social Realism, Knowledge and the Sociology of Education: Coalitions of the mind. London: Continuum.

Maude, A. (2018) 'Geography and powerful knowledge: A contribution to the debate'. International Research in Geographical and Environmental Education, 27 (2), 179-90.

Meyer, M.A. and Meyer, H. (2007) Wolfgang Klafki: Eine Didaktik fur das 21. Jahrhundert? Weinheim: Beltz.

Molin, L. and Grubbström, A. (2013) 'Are teachers and students ready for the new middle school geography syllabus in Sweden? Traditions in geography teaching, current teacher practices, and student achievement'. Norwegian Journal of Geography, 67 (3), 142-7.

Nieveen, N. and Folmer, E. (2013) 'Formative evaluation in educational design research'. In Plomp, T. and Nieveen, N. (eds) Education Design Research: Part A: An introduction. Enschede: SLO, 152-69.

Nordgren, K. (2017) 'Powerful knowledge, intercultural learning and history education'. Journal of Curriculum Studies, 49 (5), 663-82.

Persson, S. (2009) Forskningscirklar: En vägledning. Malmö: Resurscentrum för mångfaldens skola.

Pred, A. (1990) Making Histories and Constructing Human Geographies: The local transformation of practice, power relations, and consciousness. Boulder, CO: Westview Press.

Samuelsson, J. (2014) 'Ämnesintegrering och ämnesspecialisering: SO-undervisningen i Sverige 1980-2014'. Nordidactica: Journal of Humanities and Social Science Education, 1, 85-118.

Skolverket (2005) Samhällsorienterande ämnen. Nationella Utvärderingen av grundskolan 2003. Ämnesrapport till Skolverkets rapport 252.

Starrin, B. and Lundberg, B. (1993) 'Forska tillsammans! En introduktion till participatory research'. Socialmedicinsk tidskrift, 70 (4), 152-60.

Stolare, M. (2010) Samhällets cirklar: Lokala kunskapstraditioner och folkbildningens vardag i Munkfors 1965-1978. Karlstad: Karlstad University Press.

Stolare, M. (2014) 'På tal om historieundervisning: Perspektiv på undervisning i historia på mellanstadiet'. Acta Didactica Norge, 8 (1), Article 9, 1-19. Online. https://journals.uio.no/index. php/adno/article/viewFile/1101/980 (accessed 20 July 2018).

Stolare, M. (2017) 'Did the Vikings really have helmets with horns? Sources and narrative content in Swedish upper primary school history teaching'. Education 3-13: International Journal of Primary, Elementary and Early Years Education, 45 (1), 36-50.

Svingby, G. (1986) 'Integration eller ämnesläsning - en fråga om kunskapssyn'. In Kunskap och begrepp: Centrala motiv i våra läroplaner. Stockholm: Skolöverstyrelsen, 96-127.

Thrift, N. (2005) 'Torsten Hägerstrand and social theory'. Progress in Human Geography, 29 (3), 337-40.

Utbildningsdepartementet (2009) En ny betygsskala (Regeringens proposition 2008/09:66). Regeringskansliet: Stockholm.

Utbildningsdepartementet (2010) Bäst i klassen - en ny lärarutbildning. (Regeringens proposition 2009/10:89). Regeringskansliet: Stockholm.

van den Akker, J., Gravemeijer, K., McKenney, S. and Nieveen, N. (eds) (2006) Educational Design Research. London: Routledge.

VanFossen, P.J. (2005) '"Reading and math take so much of the time...": An overview of social studies instruction in elementary classrooms in Indiana'. Theory and Research in Social Education, 33 (3), 376-403.

Westbury, I. (2000) 'Teaching as a reflective practice: What might Didaktik teach curriculum?'. In Westbury, I., Hopmann, S. and Riquarts, K. (eds) Teaching as a Reflective Practice: The German Didaktik tradition. London: Routledge, 15-40.

Willbergh, I. (2016) 'Bringing teaching back in: The Norwegian NOU 'The school of the future' in light of the Allgemeine Didaktik theory of Wolfgang Klafki'. Nordic Journal of Pedagogy and Critique, 2, 111-24.

Winch, C. (2010) Dimensions of Expertise: A conceptual exploration of vocational knowledge. London: Continuum.

Winch, C. (2013) 'Curriculum design and epistemic ascent'. Journal of Philosophy of Education, 47 (1), 128-46.

Young, M.F.D. (2008) Bringing Knowledge Back In: From social constructivism to social realism in the sociology of education. London: Routledge. 
Young, M. (2014) 'Powerful knowledge as a curriculum principle'. In Young, M., Lambert, D., Roberts, C. and Roberts, M. Knowledge and the Future School: Curriculum and social justice. London: Bloomsbury Academic, 65-88.

Young, M., Lambert, D., Roberts, C. and Roberts, M. (eds) (2014) Knowledge and the Future School. London: Bloomsbury.

Young, M. and Muller, J. (2010) 'Three educational scenarios for the future: Lessons from the sociology of knowledge'. European Journal of Education, 45 (1), 11-27.

Young, M. and Muller, J. (2016) Curriculum and the Specialization of Knowledge: Studies in the sociology of education. London: Routledge. 